\title{
Host specificity and growth of kelp gametophytes symbiotic with filamentous red algae (Ceramiales, Rhodophyta)
}

Received: 23 March 2003 / Revised: 14 July 2003 / Accepted: 14 July 2003 / Published online: 10 September 2003 (C) Springer-Verlag and AWI 2003

\begin{abstract}
Kelp gametophytes were previously observed in nature living endophytically in red algal cell walls. Here we examine the interactions of two kelp species and six red algae in culture. Gametophytes of Nereocystis luetkeana (Mertens) Postels et Ruprecht became endophytic in the cell walls of Griffithsia pacifica Kylin and Antithamnion defectum Kylin, and grew epiphytically in high abundance on G. japonica Okamura and Aglaothamnion oosumiense Itono. Alaria esculenta (Linnaeus) Greville from the Atlantic coast of Nova Scotia became endophytic in Aglaothamnion oosumiense, Antithamnion defectum, Callithamnion sp., G. japonica, G. pacifica, and Pleonosporium abysicola Gardner, all from the Pacific Ocean. Some cultures were treated with phloroglucinol before infection to thicken the cell walls. The endophytic gametophytes were smaller and grew more slowly than gametophytes epiphytic on the same host. $N$. luetkeana failed to become endophytic in some of the potential hosts, and this may reflect host specificity, or culture artifacts. This work improves our understanding of the process of infection of red algae by kelp gametophytes, and broadens our knowledge of host specificity in endophytic symbioses.
\end{abstract}

Keywords Kelp gametophytes · Life histories · Phloroglucinol $\cdot$ Red algae $\cdot$ Symbiosis

Communicated by K. Lüning

C. B. Hubbard · D. J. Garbary ( ) D. M. Chiasson

Biology Department,

St. Francis Xavier University,

Antigonish, NS, B2G 2W5, Canada

e-mail: dgarbary@stfx.ca

Tel.: +1-902-8672164

Fax: +1-902-8672389

K. Y. Kim

Faculty of Earth Systems and Environmental Science and Institute of Marine Sciences,

Chonnam National University,

500-757 Kwangju, Korea

\section{Introduction}

Kelp gametophytes have been extensively studied in the laboratory, but are elusive in nature. They have occasionally been found growing on rocks, and wood, and as epiphytes on crustose coralline algae (Parke 1932; Sakai and Funano 1964; Funano 1969; Kaneko 1973; Kain 1979). Artificial substrata placed in nature have also successfully been utilized for settlement of kelp gametophytes (e.g., Reed et al. 1988). More recently, gametophytes have been found growing endophytically in the cell walls of red algae where they become reproductive and produced juvenile sporophytes (Garbary et al. 1999a, 1999b). Initially, 17 red algal species from western North America were observed with endophytic gametophytes. They were most common in filamentous hosts, and hundreds of gametophytes were observed in many individual host thalli. To date, endophytic gametophytes have only been observed either in situ or in vitro in or from the Pacific Ocean.

Because kelp is so important in structuring its habitat, many red algal species have a close relationship with them. There are some red algae that are obligate epiphytes of kelp [e.g., Porphyra gardneri (Smith et Hollenberg) Hawkes 1977], and many more that are facultative epiphytes (e.g., Tokida 1960). In addition, hundreds of red algal species thrive in the habitat created by kelp sporophytes in kelp forests around the world. The chemical ecology of interactions between kelp and red algae has not been well studied; however, chemicals released from kelp may function as growth regulators of red algae since they can modify red algal morphology (Fries 1972). Swanson and Druehl (2002) have shown that phlorotannin exudates from kelp attenuate UVB radiation and provide a possible protection mechanism for kelp spores. By inference, this protection can be extended to the entire community. Endophytic gametophytes are yet another example of the relationship between various kelp and red algae.

The objectives of the present work were to establish whether or not an Atlantic kelp species could develop 
endophytic gametophytes, and to observe the endophytic development of two kelp species within a range of potential host species. In addition, we show that phloroglucinol can modify cell wall thickness of red algae in culture, and that this compound and its oxidized derivatives may play a role in the red algal, kelp gametophyte symbiosis.

\section{Methods}

Source of materials

Reproductive fronds of Nereocystis luetkeana (Mertens) Postels et Ruprecht were collected from drift fronds and an attached bed near Friday Harbor Laboratories, San Juan Island, Washington State $\left(48^{\circ} 31^{\prime} \mathrm{N}, 123^{\circ} 01^{\prime} \mathrm{W}\right)$. Reproductive fronds of Alaria esculenta (Linnaeus) Greville were collected as drift material from Tor Bay Provincial Park on the Atlantic coast of Nova Scotia $\left(45^{\circ} 12^{\prime} \mathrm{N}, 61^{\circ}\right.$ $\left.22^{\prime} \mathrm{W}\right)$. Sori were rinsed and wiped to reduce contamination, then cut from the plants, wrapped in damp paper towel, and refrigerated overnight. They were immersed in Tyndallised seawater to induce release of zoospores. About $25 \mathrm{ml}$ of dense spore suspension was inoculated into each $100 \mathrm{ml}$ of culture medium. Spore densities were not determined but were sufficient to obtain a dense carpet of gametophytes on the bottom of dishes.

Unialgal cultures of six filamentous red algae (Table 1) were used as potential hosts. Cultures of Aglaothamnion oosumiense Itono, Antithamnion defectum Kylin, Callithamnion sp., Griffithsia japonica Okamura, G. pacifica Kylin, and Pleonosporium abysicola Gardner all originated in the Pacific Ocean, and all of these genera have been observed as hosts for kelp gametophytes (Garbary et al. 1999b; Kim and Garbary 1999). Callithamnion sp. and $P$. abysicola were not used with $N$. luetkeana, but all six species were used with Alaria esculenta. Clumps of each experimental host were 2-3 cm diameter at spore inoculation. Plants were placed in storage jars with about $100 \mathrm{ml}$ VS5 medium (Guiry and Cunningham 1984), 1-5 coverslips, and approximately $25 \mathrm{ml}$ of zoospore inoculum. $\mathrm{GeO}_{2}$ was not used to control diatoms because of negative effects on gametophyte growth. Medium was changed every 2 weeks.

Cultures were maintained at $13^{\circ} \mathrm{C}$ with constant light provided by cool-white fluorescent tubes at $10 \mu \mathrm{mol} \mathrm{cm} \mathrm{cm}^{-2}$. The $N$. luetkeana-infected plants, however, were kept for the first 8 days at $10^{\circ} \mathrm{C}$ with fluorescent room lights supplemented by light from windows and $10-12 \mathrm{~h}$ of darkness per day. After the first 8 days, these cultures were kept in the same $13^{\circ} \mathrm{C}, 24 \mathrm{~h}$ light growth chamber as described above.

Phloroglucinol treatments

Unlike red algae from nature, our red algal cultures typically had thin cell walls. To thicken the cell walls, red algal cultures were exposed to $0.001 \%, 0.01 \%$, and $0.1 \%(\mathrm{w} / \mathrm{v})$ solutions of phloroglucinol (1,3,5-trihydroxybenzene, P-3502 from Sigma, St. Louis) dissolved in VS5 medium. In one experiment, only cells 1-6 at filament apices were measured for cell wall thickness. In a second experiment, cell walls from random cells were measured. Cell walls were measured to the nearest $0.5 \mu \mathrm{m}$ at $1200 \times$ magnification. Phloroglucinol solutions were used fresh or aged for 4 days at $13^{\circ} \mathrm{C}$ prior to start of experiments. Phloroglucinol media were replenished at 2- to 7- day intervals. Cultures were treated with $150 \mathrm{mg} \mathrm{l}^{-1}$ penicillin for $48 \mathrm{~h}$ according to Hoshaw and Rosowski (1974) to reduce bacterial growth in phloroglucinol exposed cultures. Length of exposure varied, but 2 weeks was the most common. The $N$. luetkeana-infected algae were treated with $0.01 \%$ and $0.1 \%$ phloroglucinol from days 32 to 46 post culture initiation. The Alaria esculenta infection experiment was performed with both untreated hosts and hosts pre-treated with $0.1 \%$ phloroglucinol for 2 weeks. Statistical analysis involved one-way ANOVA (SYSTAT 1992)

\section{Microscopy}

The cultures were examined microscopically after 2 days, 1 week, and then every week for up to 3.5 months. Many cultures were discarded because of bacterial and diatom contamination. Photographs were taken using a (Diagnostic Instruments, Sterling Heights, Michigan) Spot 2 low light digital camera on a Zeiss Photomicroscope III (Oberkochen, Germany) and edited using Photoshop 5.5 for Windows.

\section{Results}

Phloroglucinol and cell walls

Phloroglucinol thickened the cell walls of all of red algae tested, although the extent of the thickening varied with species, part of the thallus, concentration (Tables 2, 3),

Table 1 Sources of red algal cultures. See Starr and Zeikus (1987) for details of UTEX isolates

\begin{tabular}{ll}
\hline Species & Source \\
\hline Aglaothamnion oosumiense Itono & Isolated 06/ 94 at Echondo, Korea, by H.G. Choi, (CHG 001), see Chah and Kim (1998) \\
Antithamnion defectum Kylin & UTEX No. 2261 \\
Callithamnion sp & Isolated 01/00 from Friday Harbor, San Juan Island, Wash., USA by C. Hubbard \\
Griffithsia japonica Okamura & Isolated 5/02 from Dolsando, Korea by Y.S. Oh (CHG007) \\
G. pacifica Kylin & UTEX No. 2456 \\
Pleonosporium abysicola Gardner & Isolated 01/00 from Friday Harbor, San Juan Island, Wash., USA by C. Hubbard \\
\hline
\end{tabular}

Table 2 Cell wall thickness of cells $1-5$ in apices $(n=30)$ of five species of red algae exposed to $0.01 \%$ phloroglucinol for 17 days (mean \pm SD $\mu \mathrm{m}$ ). Bold type indicates that the cell walls were significantly thicker than control $(P \leq 0.05$; one way ANOVA)

\begin{tabular}{llll}
\hline Species & \multicolumn{2}{l}{ Treatment } & \\
\cline { 2 - 4 } & Control & Aged $0.01 \%$ phloroglucinol & Fresh $0.01 \%$ phloroglucinol \\
\hline Aglaothamnion oosumiense & $1.5 \pm 0.4$ & $\mathbf{3 . 7 \pm 0 . 8}$ & $\mathbf{4 . 8} \pm \mathbf{4 . 6}$ \\
Antithamnion defectum & $1.7 \pm 0.3$ & $\mathbf{3 . 7 \pm 1 . 5}$ & $\mathbf{2 . 7 \pm 1 . 1}$ \\
Callithamnion sp. & $1.8 \pm 0$ & $\mathbf{3 . 2 \pm 0 . 7}$ & $\mathbf{3 . 1 \pm 0 . 6}$ \\
Griffithsia pacifica & $4.3 \pm 4.7$ & $\mathbf{9 . 7} \pm \mathbf{6 . 4}$ & $\mathbf{1 0 . 1} \pm \mathbf{4 . 5}$ \\
Pleonosporium abysicola & $1.8 \pm 0$ & $\mathbf{2 . 8} \pm \mathbf{0 . 5}$ & $\mathbf{3 . 9} \pm \mathbf{1 . 6}$ \\
\hline
\end{tabular}


Table 3 Cell wall thickness of random cells $(n=20)$ of three species of red algae exposed to phloroglucinol for 10 days (mean \pm SD $\mu \mathrm{m}$ ). Bold type indicates that cell walls were significantly thicker than control $(P \leq 0.05$; one way ANOVA)

\begin{tabular}{llrll}
\hline Species & \multicolumn{4}{l}{ Treatment $(\%$ phloroglucinol) } \\
\cline { 2 - 5 } & Control & \multicolumn{1}{c}{$0.1 \%$} & $0.01 \%$ & $0.001 \%$ \\
\hline $\begin{array}{l}\text { Aglaothamnion } \\
\text { oosumiense }\end{array}$ & $4.5 \pm 3.7$ & $\mathbf{6 . 9} \pm \mathbf{2 . 9}$ & $4.8 \pm 2.1$ & $4.4 \pm 2.5$ \\
$\begin{array}{c}\text { Griffithsia pacifica } \\
\begin{array}{c}\text { Pleonosporium } \\
\text { abysicola }\end{array}\end{array}$ & $3.0 \pm 2.4$ & $\mathbf{1 5 . 0} \pm \mathbf{4 . 0}$ & $\mathbf{7 . 9} \pm \mathbf{3 . 9}$ & $3.8 \pm 2.4$ \\
\hline
\end{tabular}

age of solution, and length of exposure. The untreated red algal cultures had thin walls, typically $1.5-4.5 \mu \mathrm{m}$, especially near apical cells (Table 2). Cell wall thickness typically increases with cell size. Treatment with freshly prepared or aged phloroglucinol media resulted in cell walls that were typically $50-100 \%$ thicker than control plants. In addition to having greater mean cell wall thickness, the phloroglucinol-treated walls had greater variance (Table 2). The greatest increase in wall thickness occurred in G. pacifica, where a 500\% increase occurred in $0.1 \%$ phloroglucinol (Table 3 ).
Kelp spores are 6-8 $\mu \mathrm{m}$ in diameter (Fig. 2A-E). Consequently, most of the penetration occurred on hosts that were pre-treated with phloroglucinol. This thickened the walls to mean thicknesses of 6.5-15 $\mu \mathrm{m}$ (Fig. 3). Higher concentration or prolonged exposure to phloroglucinol caused the red algae to sicken and die, and promoted bacterial growth. We minimized these negative effects by lowering phloroglucinol concentrations, aging the solutions at least 4 days, and using penicillin when necessary.

As phloroglucinol solutions age they oxidize, and turn yellow and then orange. The darkening slows considerably after about 4 days. The higher the concentration of phloroglucinol, the darker the solution becomes. In our experiments, $0.1 \%$ or $0.01 \%$ phloroglucinol aged at least 4 days usually thickened the walls enough to be useful, with minimal plant mortality, provided a 2 week exposure was possible. $0.1 \%$ was more effective when shorter exposure times were needed.
Fig. 1A-F Nereocystis luetkeana gametophytes. Scale bars $25 \mu \mathrm{m}$. A Gametophytes growing on a coverslip, 26 days old. B Gametophytes growing epiphytically wrapped around Aglaothamnion oosumiense, 27 days old. Cell walls are too thin for gametophytes to embed. C Gametophytes epiphytic on $A n$ tithamnion defectum, 27 days old. Host cell walls are too thin for gametophytes to embed. D Gametophytes epiphytic on Griffithsia japonica, 27 days old. E Gametophytes epiphytic on $G$. pacifica, 27 days old. $\mathbf{F}$ Gametophytes embedded in $G$. pacifica cell walls at junction between cells where the wall is thick. Arrows indicate gametophytes
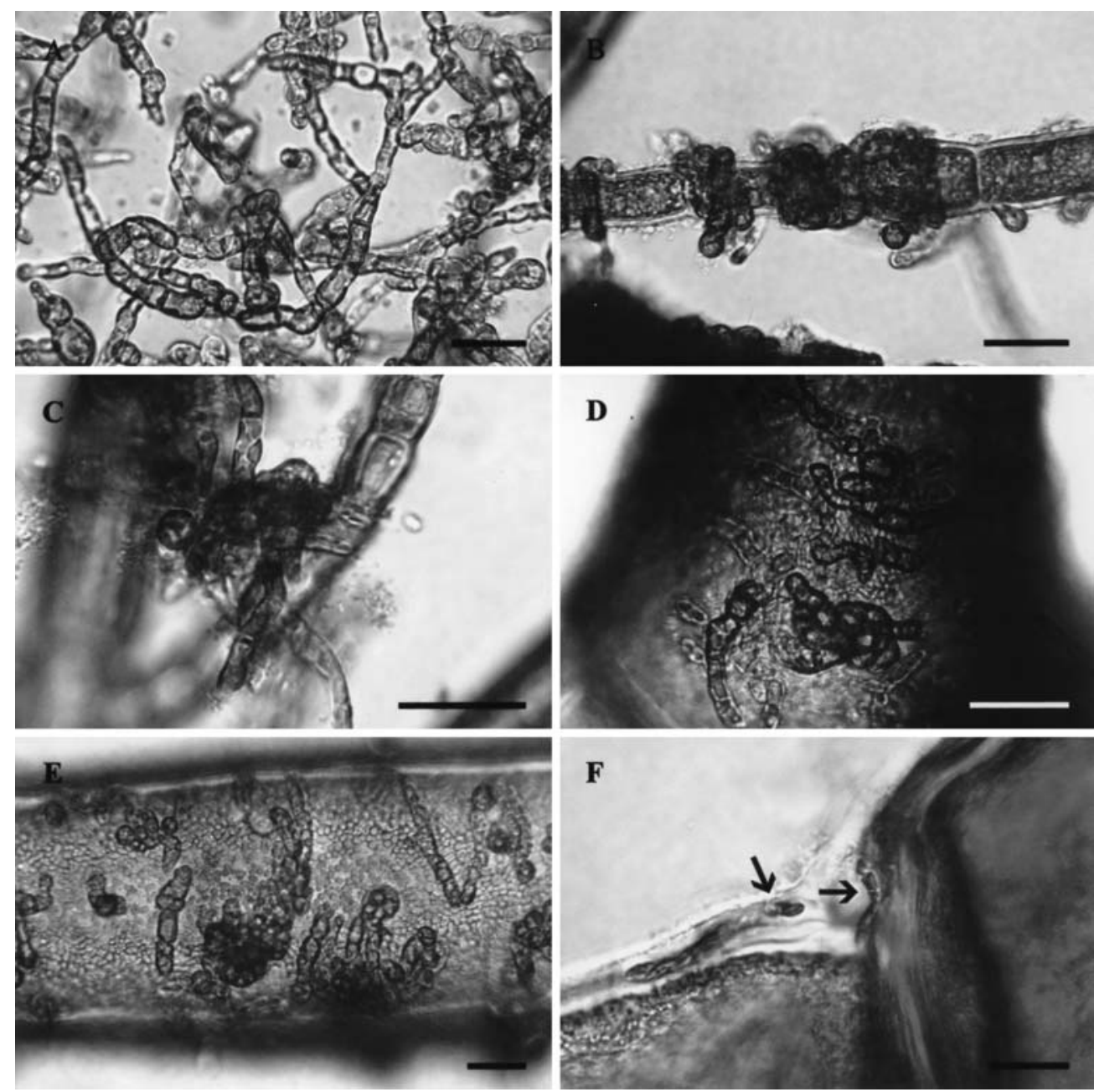
Fig. 2A-K Alaria esculenta gametophytes. Scale bars $20 \mu \mathrm{m}$. A Gametophytes attached to a coverslip, 2 days old. The empty spore, germ tube and first gametophytic cell are present. B Gametophytes attached to a cover slip, 7 days old. The empty spore is still visible. C Gametophytes attached to Aglaothamnion oosumiense, 2 days old. D Gametophytes attached to $A n$ tithamnion defectum, 2 days old. E Gametophyte attached to Callithamnion sp., 2 days old. Appears to have attempted, and failed, to become embedded in the cell wall, which is far too thin. F Gametophyte attached to G. japonica, 2 days old. $\mathbf{G}$ Gametophyte attached to $G$. pacifica, 2 days old. H Gametophyte attached to Pleonosporium abysicola, 15 days old. In this case the cell wall was thick enough, but the gametophyte still failed to penetrate. I Antheridia on a 30-day-old gametophyte attached to $P$.

abysicola. J Oogonium on a 44day-old gametophyte attached to $P$. abysicola. K Sporophyte growing on $P$. abysicola 52 days after initial spore release
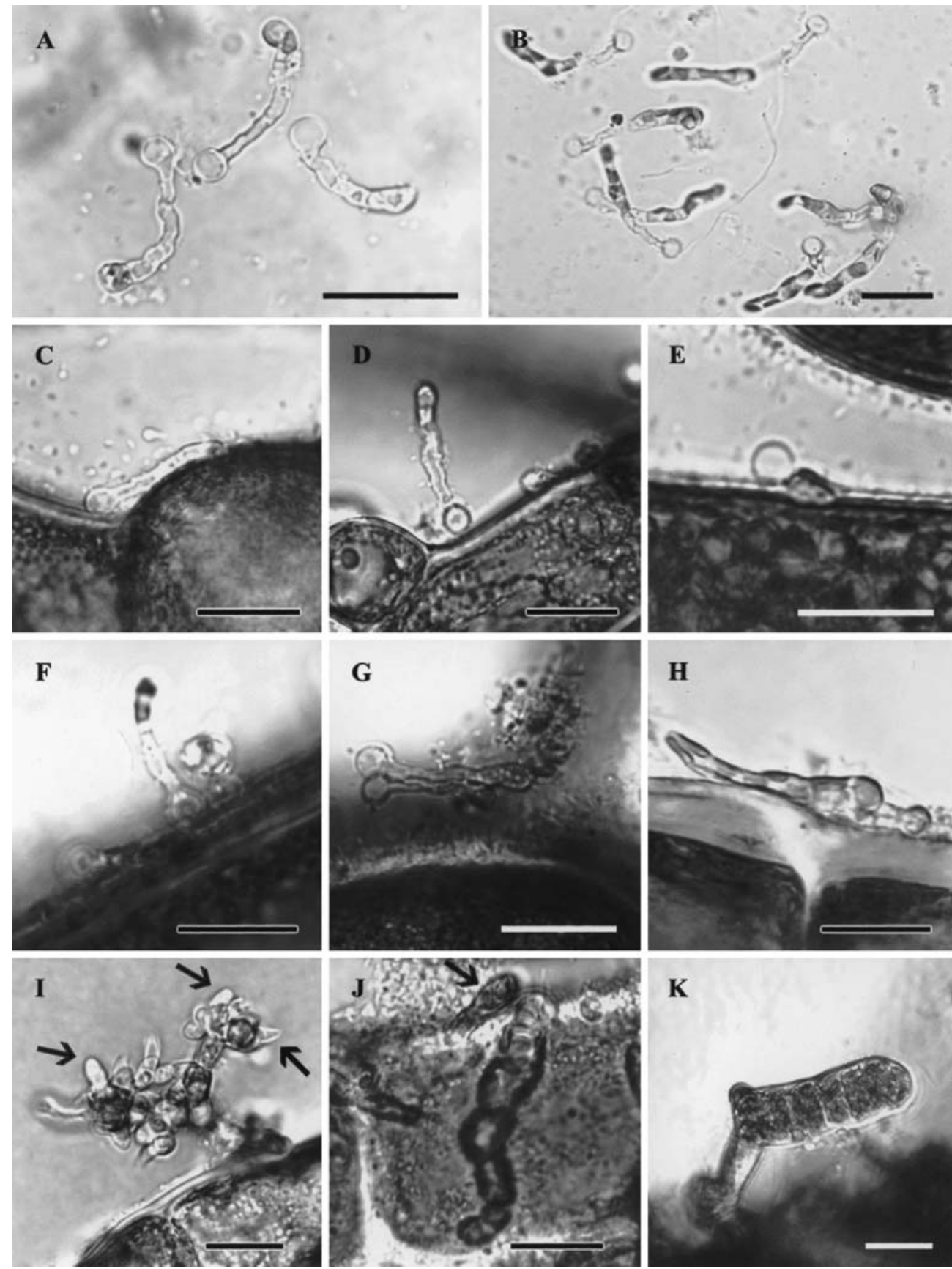

H

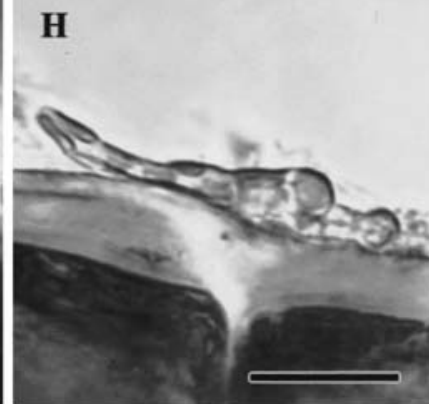

$\mathbf{K}$

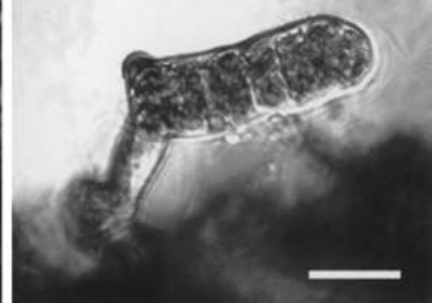

\section{Infection}

The dense zoospore inoculum was convenient for observing the gametophytes, although this made it impossible to judge whether the zoospores showed any substrate preferences.

\section{Nereocystis luetkeana}

Spores of $N$. luetkeana germinated on all surfaces, including the red algal cell walls (Fig. 1A-E). The spores produced germ tubes, through which the cytoplasm flowed to form the initial gametophyte cell. Free-living gametophytes quickly grew to over a dozen cells long (Fig. 1A). Epiphytic gametophytes were usually appressed to the host cell (Fig. 1D, E), and sometimes wrapped right around (Fig. 1B). The empty spore wall was usually still present 4 weeks after germination, and swelled slightly as it degraded.

At the time of inoculation, the red algae had not been treated with pholoroglucinol. The cell walls were mostly thinner than the diameter of the zoospores and gametophytes (Fig. 1B). Exceptions were older cells, or the junction between cells where walls could be up to $20 \mu \mathrm{m}$ thick, especially in Griffithsia (Fig. 1F). Only a few 

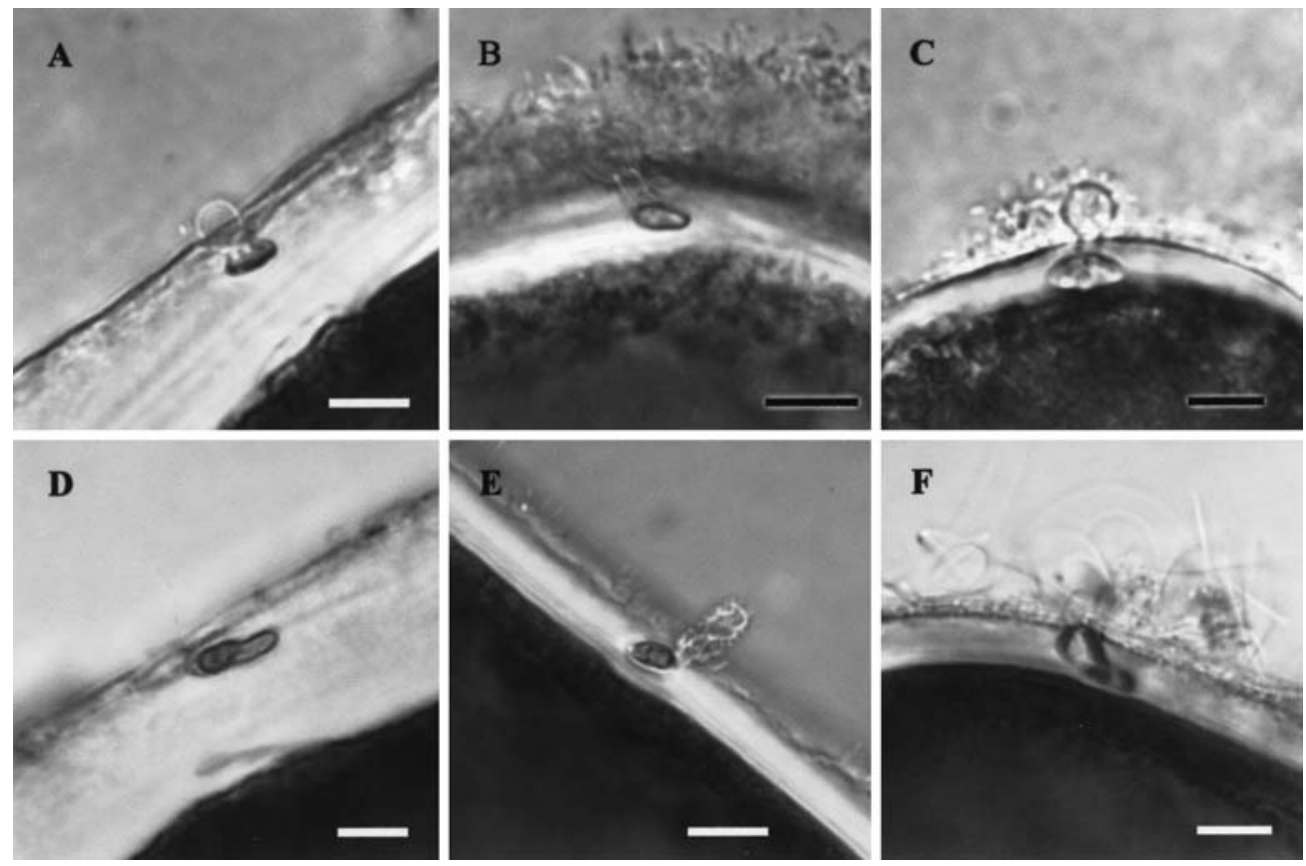

Fig. 3A-F Alaria esculenta gametophytes with host red algae. Scale bars $10 \mu \mathrm{m}$. A Gametophyte embedded in the cell wall of $G$. japonica, 2 days old. The empty spore walls are still clearly visible resting on the host cell wall. B Gametophyte embedded in the cell wall of G. pacifica, 2 days old. The empty spore wall is still clearly visible resting on the host cell wall. $\mathbf{C}$ Gametophyte embedded in

gametophytes were observed as endophytes, the first being a two-cell gametophyte endophytic in Antithamnion defectum found on day 19 . On day 32, phloroglucinol treatment was initiated to determine if epiphytic gametophytes would become endophytic if the walls were thickened. A few gametophytes were found in G. pacifica on day 46, completely embedded at the junction between cells (Fig. 1F). The location, size, and position all suggested that these endophytic plants had been present since germination and had not been discovered. Cell wall thickening did not cause noticeable increase in endophytic kelp gametophyte density.

\section{Alaria esculenta}

Spores of Alaria esculenta germinated in high densities on all surfaces, including the red algae (Fig. 2). Germ tubes were produced and cytoplasm flowed out of the spore to form a gametophyte cell (Fig. 2A-G), as with $N$. luetkeana, but the empty spore did not persist much past a week. Epiphytic gametophytes grew very large, to several dozen cells, and often wrapped themselves right around the host cells. There were also upright gametophytes, and as time passed some of these became detached, forming clumps. For example, a dense population on one cover slip became detached as a whole. Antheridia developed on some gametophytes and were first observed on day 30 (Fig. 2I). Oogonia, which were much less common than the cell wall of $P$. abysicola, 2 days old. The empty spore walls are still clearly visible resting on the host cell wall. D Gametophyte, several cells long, embedded in the cell wall of $G$. japonica, 7 days old. E Gametophyte, several cells long, embedded in the cell wall of G. pacifica, 10 days old. F Gametophyte, several cells long, embedded in the cell wall of $P$. abysicola, 7 days old

antheridia, were first observed on day 44 (Fig. 2J). On day 50, the first of two sporophytes was observed attached to the red algae (Fig. 2K). Both resulted from epiphytic gametophytes. Many more sporophytes developed on the cover slips and the sides of the dish. These were moved to a Petri dish where half were able to re-attach and all continued growing.

Endophytic gametophytes were observed in all available hosts when the walls were thick enough. The spores settled on the cell wall and germ tube and gametophyte cells were embedded in the host (Fig. 3A-C). The empty spore could often still be seen resting on the host wall a week later (Fig. 3E), although it was usually degraded. The embedded gametophytes grew slowly after the first 2 days (Fig. 3D-F), rarely reaching three cells in length. Apart from the attached spore, 2-day-old gametophytes look very similar to week-old or month-old gametophytes (Fig. 3). No gametophytes were observed with both epiphytic and endophytic sections.

Among the untreated red algal cultures, the cell walls were thickest and the gametophytes most common on $P$. abysicola, G. japonica, and G. pacifica. Endophytes were extremely rare on the other three hosts. Pre-treating the hosts with $0.1 \%$ phloroglucinol resulted in thick walls and frequent endophytes in all six species. 


\section{Discussion}

Phloroglucinol

The cell walls of filamentous red algae in nature are often much thicker than those in cultures. Phloroglucinol was useful for inducing cell walls with a thickness appropriate for the infection experiments. Preliminary data show that similar results can be induced using a seawater extract of Laminaria saccharina (Linnaeus) Lamouroux (Hubbard, unpublished), and we assume that it is the tannin components that are the stimulus for this response. Seawater in kelp beds and Fucus/Ascophyllum beds contains a variety of compounds released from the brown algae, including a large number of phenolic compounds, of which phloroglucinol is the simplest (Craigie and McLachlan 1964; Sieburth 1969; Kroes 1970; Kremer 1981; Ragan 1981). These compounds play various roles in brown algae (Schoenwaelder 2002a, 2002b). The concentration of phlorotannins is high enough in kelp beds to provide UV protection (Swanson and Druehl 2002). Such concentrations may be a factor which induces thickening of red algal walls in situ. It may be that the secretion of phlorotannins has an adaptive role in the kelp life history. Thus, red algae in a kelp forest may be responding to the tannins, with their thicker walls making them more suitable as hosts for the kelp gametophytes.

Stylonema alsidii (Zanardini) Drew [as Goniotrichum elegans (Chauvin) Zanardini] developed a pale, calluslike morphology after extended periods in laboratory cultivation (Fries 1972). Phenolic compounds, including phloroglucinol, returned the cultures to their dark purple, filamentous morphology. Thus, Fries demonstrated that these compounds could function as growth regulators of red algae. Here, we show that these compounds may participate in the interaction between kelp gametophytes and filamentous red algae.

\section{Characteristics of the symbiosis}

We learned two things about the endophytic process: (1) the gametophytes burrow into the cell walls rather than inducing the wall to grow around them, and (2) endophytism can only be initiated during spore settlement and germination. If gametophytes cause the wall to grow up around them, they should be able to become endophytic in thin-walled cells, which they are not. Even in nature, the gametophytes are found in the older, thickwalled cells of the plants or in the walls between adjoining cells.

We previously suspected that endophytes became endophytic only during zoospore settlement and germination. There is a rapid succession of changes at that time, including the secretion of materials such as adhesive plaques (Oliveira et al. 1980). There have been no observations of vegetative kelp gametophytes with both epiphytic and endophytic portions. After inoculation, we began observing endophytic gametophytes within 2 days, as did Kim and Garbary (1999), or not at all. While there was no noticeable difference between the epiphytic and free-living gametophytes, there was a considerable difference between the endophytes and the epiphytes/freeliving gametophytes. As well as having more compact and fewer cells, the endophytes did not become reproductive during up to 3.5 months of observation.

Reproductive structures have been observed in endophytic gametophytes in situ (Garbary et al. 1999a, 1999b), but it is possible that endophytes of many kelp species are exclusively vegetative, or only reproduce in some hosts. Other explanations for the lack of reproduction are that endophytes reproduce under different conditions (i.e., light, temperature) than free living/epiphytic gametophytes, or that endophytes must reach a minimum size. The requirements of free-living gametophytes have been well studied (e.g., Lüning and Neushul 1978; Druehl and Boal 1981; Izquierdo et al. 2002), now it is useful to undertake similar work on endophytic gametophytes.

Kelp gametophytes have been compared to the seed banks of terrestrial plants (Hoffman and Santelices 1991; Edwards 2000). However, the relative growth rates of the endophytic and free-living gametophytes suggest that the seed bank analogy applies to the endophytes more than to the free-living gametophytes. Endophytism seems to allow Alaria esculenta and N. luetkeana gametophytes to enter into a sort of stasis. The free-living gametophytes could reproduce first, while the more slowly growing endophytic gametophytes could form a seed bank that produces sporophytes over several months, providing a back-up source of sporophytes. This would be most beneficial for annual species such as Nereocystis.

\section{Biogeography}

Previously, endophytic kelp gametophytes have only been observed in the Pacific Ocean (Garbary et al. 1999a, 1999b; Kim and Garbary 1999). However, since gametophytes of Alaria esculenta from Nova Scotia become endophytic in culture, it is likely that kelp endophytes occur in the Atlantic Ocean but have not been found. The lack of Atlantic observations probably reflects a shorter search, searches in the wrong place and/or season, and possibly a lower density of endophytic gametophytes. Because the density and diversity of kelp and red algal species is different in the Atlantic than the Pacific, the density of endophytic kelp gametophytes could be much lower in the Atlantic.

\section{Future Investigations}

There is still a lot to learn about the kelp gametophyte/red algal symbiosis. The broadest question is: how widespread is the symbiosis? There are hundreds of species of kelp and an enormous number of possible kelp/red algal combinations. Most kelp species investigated so far have become endophytic [Alaria esculenta, N. luetkeana, 
Laminaria groenlandica Rosenvinge, and Undaria pinnatifida (Harvey) Suringar became endophytic, Laminaria religiosa Miyabe did not (Garbary et al. 1999a; Kim and Garbary 1999)]. N. luetkeana did not become endophytic in all possible hosts; however, this was probably a culture artifact (thin walls), not host specificity.

Kim and Garbary (1999) suggested chemotaxis as $U$. pinnatifida (which became endophytic) settled on the host in much higher density than $L$. religiosa (which did not become endophytic). The zoospores of Pterygophora californica Ruprecht and Macrocystis pyrifera (L.) C. Agardh are chemotactically drawn to nutrients (Amsler and Neushul 1989, 1990). It is possible that the zoospores find the red algae based on released photosynthate (Kremer 1981) or chemical signals from the red algae.

The benefits and drawbacks of the endophytic lifestyle for kelp gametophytes remain unresolved. The small morphology and low density of endophytic gametophytes in culture suggests drawbacks. However, both free-living and endophytic gametophytes can be found in nature (e.g., Kain 1979; Garbary et al. 1999a, 1999b) implying that both lifestyles represent adaptations. Symbiosis could provide protection from grazing and sedimentation, or improve access to light. Fine sediments reduce kelp spore attachment and survival (Devinny and Volse 1978) and the understories of kelp stands experience higher levels of sedimentation than adjacent cleared areas (Eckman et al. 1989; Duggins et al. 1990). Anderson et al. (1997) found that juvenile Ecklonia were grazed less when they grew on adult holdfasts. Similarly, red algal hosts may inhibit herbivores from accessing the gametophytes, or the host surface may be more resistant than an epilithic gametophyte (Padilla 1985). It is also possible that endophytes have no better chance of surviving than free-living gametophytes, but the increased diversity of life history strategy may increase the overall likelihood of gametophytes surviving.

Acknowledgements We thank D.O. Duggins for collecting Nereocystis luetkeana and Friday Harbor Laboratories, University of Washington, for hosting C.B. Hubbard during part of this work. This research was supported by a grant from the Natural Sciences and Engineering Research Council of Canada to D.J. Garbary.

\section{References}

Amsler CD, Neushul M (1989) Chemotactic effects of nutrients on spores of the kelps Macrocystis pyrifera and Pterygophora californica. Mar Biol 102:557-564

Amsler CD, Neushul M (1990) Nutrient stimulation of spore settlement in the kelps Pterygophora californica and Macrocystis pyrifera. Mar Biol 107:297-304

Anderson RJ, Carrick P, Levitt GJ, Share A (1997) Holdfasts of adult kelp Ecklonia maxima provides refuges from grazing for recruitment of juvenile kelps. Mar Ecol Prog Ser 159:265-273

Chah O-K, Kim GH (1998) Life history and taxonomy of Aglaothamnion oosumiense Itono (Ceramiaceae, Rhodophyta). Algae 13:199-206

Craigie JS, McLachlan J (1964) Excretion of colored ultravioletabsorbing substances by marine algae. Can J Bot 42:23-33
Devinny JS, Volse LA (1978) Effects of sedimentation on the development of Macrocystis pyrifera gametophytes. Mar Biol 48:343-348

Druehl LD, Boal R (1981) Manipulation of the laminarialean lifecycle and its consequences for kombu mariculture. Proc Int Seaw Symp 10:575-580

Duggins DO, Eckman JE, Swell AT (1990) Ecology of understorey kelp environments. II. Effects of kelps on recruitment of benthic invertebrates. J Exp Mar Biol Ecol 143:27-45

Eckman JE, Duggins DO, Sewell AT (1989) Ecology of understorey kelp environments. I. Effects of kelps on flow and particle transport near the bottom. J Exp Mar Biol Ecol 129:173-187

Edwards MS (2000) The role of alternate life-history stages of a marine macroalga: a seed bank analogue? Ecology 81:24042415

Fries L (1972) The influence of phenolic compounds on Goniotrichum elegans (Chauv.). Proc Int Seaw Symp 7:575-579

Funano T (1969) Observation on the female gametophytes and the microscopic sporophytes of Laminaria religiosa Miyabe. Rep Hokkaido Fish Exp Stn 10:43-50

Garbary DJ, Kim KY, Klinger T, Duggins D (1999a) Preliminary observations on the development of kelp gametophytes endophytic in red algae. Hydrobiologia 398/399:247-252

Garbary DJ, Kim KY, Duggins D (1999b) Red algae as hosts for endophytic kelp gametophytes. Mar Biol 135:35-40

Guiry MD, Cunningham EM (1984) Photoperiodic and temperature responses in the reproduction of north-eastern Atlantic Gigartina acicularis (Rhodophyta: Gigartinales). Phycologia 23:357367

Hawkes MW (1977) A field, culture and cytological study of Porphyra gardneri (Smith \& Hollenberg) comb. nov., (=Porphyrella gardneri Smith \& Hollenberg, Bangiales, Rhodophyta). Phycologia 16:457-469

Hoffman AJ, Santelices B (1991) Banks of algal microscopic forms: hypotheses on their functioning and comparisons with seed banks. Mar Ecol Prog Ser 79:185-194

Hoshaw RW, Rosowski JR (1974) Models for microscopic algae. In: Stein JR (ed) Handbook of phycological methods. Culture methods and growth measurements. Cambridge University Press, Cambridge, pp53-68

Izquierdo JL, Perez-Ruzafa I, Gallardo T (2002) Effects of temperature and photon fluence rate on gametophytes and young sporophytes of Laminaria ochroleuca Pylaie. Helgol Mar Res 55:285-292

Kain JM (1979) A view of the genus Laminaria. Ocean Mar Biol Annu Rev 17:101-161

Kaneko T (1973) Morphology of the female gametophyte and young sporophyte of Laminaria japonica var. ochotensis Okamura in nature. Sci Rep Hokkaido Fish Exp Stn 15:1-8

Kim KY, Garbary DJ (1999) Artificial reestablishment of the kelp and red algal symbiosis. Korean J Biol Sci 3:243-246

Kremer BP (1981) Carbon metabolism. In: Lobban CS, Wynne MJ (eds) The biology of seaweeds. University of California Press, Berkeley, Calif., pp493-533

Kroes HW (1970) Excretion of mucilage and yellow-brown substances by some brown algae from the intertidal zone. Bot Mar 13:107-110

Lüning K, Neushul M (1978) Light and temperature demands for growth and reproduction of laminarian gametophytes in southern and central California. Mar Biol 45:297-309

Oliveira L, Walker DC, Bisalputra T (1980) Ultrastructural, cytochemical, and enzymatic studies on the adhesive "plaques) of the brown algae Laminaria saccharina (L.) Lamour. and Nereocystis luetkeana (Mert.) Post. et Rupr. Protoplasma 104:1-15

Padilla DK (1985) Structural resistance of algae to herbivores: a biomechanical approach. Mar Biol 90:103-109

Parke MW (1932) Port Erin: report of the algologist. Rep Mar Biol Stn Port Erin 45:18-21 
Ragan MA (1981) Chemical constituents of seaweeds. Lobban CS, Wynne MJ (eds) The biology of seaweeds. University of California Press, Berkeley, Calif., pp589-626

Reed DC, Laur DR, Ebeling AW (1988) Variation in algal dispersal and recruitment: the importance of episodic events. Ecol Monogr 58:321-335

Sakai Y, Funano T (1964) Observation on the female gametophytes and the microscopic sporophytes of Laminaria religiosa from Oshoro Bay, Hokkaido, Japan. Sci Rep Hokkaido Fish Exp Stn 2:1-6

Schoenwaelder MEA (2002a) The occurrence and significance of physodes in brown algae. Phycologia 41:125-139
Schoenwaelder MEA (2002b) Physode distribution and the effect of 'Thallus sunburn' in Hormosira banksii (Fucales, Phaeophyceae). Bot Mar 45:262-266

Sieburth J McN (1969) Studies on algal substances in the sea. III. The production of extracellular organic matter by littoral marine algae. J Exp Mar Biol Ecol 3:290-309

Starr RC, Zeikus JA (1987) UTEX - the culture collection of algae at the University of Texas at Austin. J Phycol 23(suppl):1-47

Swanson AK, Druehl LD (2002) Induction, exudation and the UV protective role of kelp phlorotannins. Aquat Bot 73:241-253

SYSTAT (1992) Statistics, ver. 5.2. SYSTAT Inc., Evanston, Il.

Tokida J (1960) Marine algae epiphytic on Laminariales plants. Bull Fac Fish Hokkaido Univ 11:73-105 